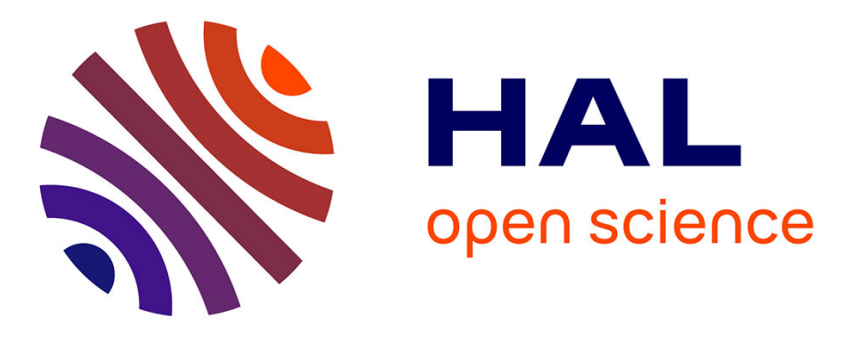

\title{
Applying deep learning for agricultural classification using multitemporal SAR Sentinel-1 for Camargue, France
}

E. Ndikumana, Dinh Ho Tong Minh, N. Baghdadi, Dominique Courault, Laure L. Hossard

\section{To cite this version:}

E. Ndikumana, Dinh Ho Tong Minh, N. Baghdadi, Dominique Courault, Laure L. Hossard. Applying deep learning for agricultural classification using multitemporal SAR Sentinel-1 for Camargue, France. Image and Signal Processing for Remote Sensing XXIV, Society of Photographic Instrumentation Engineers (SPIE). Cardiff, GBR., Sep 2018, Berlin, Germany. pp.13, 10.1117/12.2325160 . hal02608491

\section{HAL Id: hal-02608491 https://hal.inrae.fr/hal-02608491}

Submitted on 2 Jun 2020

HAL is a multi-disciplinary open access archive for the deposit and dissemination of scientific research documents, whether they are published or not. The documents may come from teaching and research institutions in France or abroad, or from public or private research centers.
L'archive ouverte pluridisciplinaire HAL, est destinée au dépôt et à la diffusion de documents scientifiques de niveau recherche, publiés ou non, émanant des établissements d'enseignement et de recherche français ou étrangers, des laboratoires publics ou privés. 


\section{Applying deep learning for agricultural classification using multitemporal SAR Sentinel-1 for Camargue, France}

Paper 10789-39

Author(s): Emile Ndikumana, Dinh Ho Tong Minh, Nicolas Baghdadi, Institut National de Recherche en Sciences et Technologies Pour l'Environnment et l'Agriculture (France); Dominique Courault, Laure Hossard, Institut National de la Recherche Agronomique (France)

The development and improvement methods to map agricultural land cover is a timely challenge, especially for radar images. This is due to the speckle noise nature of radar, leading to a less intensive use of radar rather than optical images. Recently, the European Space Agency Sentinel-1 constellation is a satellite system providing the global coverage of Synthetic Aperture Radar (SAR) with a 6-days revisit period at a high spatial resolution about $20 \mathrm{~m}$. These data are valuable aids in providing the spatial information of agricultural crops. The aim of this paper is to provide a better understanding of the capabilities of Sentinel-1 radar images for agricultural land cover mapping through the use of deep learning techniques. Analysis is carried out on a multitemporal Sentinel-1 data over an area around Camargue, France. This data set was processed in order to produce an intensity radar data stack from May 2017 to September 2017. We revealed that even with classical machine learning approaches $\mathrm{K}$ nearest neighbors, random forest, and support vector machine), the good performance classification could be achieved with F-measure/Accuracy greater than $94 \%$ and Kappa coefficient better than 0.92 . We found that the results of the two deep recurrent neural network (RNN)-based classifiers clearly outperformed the classical approaches. Finally, our analyses in Camargue show that the same performance of two RNN-based classifiers is on the Rice class, the most dominant practice of this region, with the F-measure metric of $99.5 \%$. These results thus highlight that in the next future, these RNN-based techniques will play an important role in the analysis of remote sensing time series. 